\title{
QUANTIFYING AND MAPPING THE EVOLUTION OF A LEADER JOURNAL IN THE FIELD OF CIVIL ENGINEERING
}

\author{
Ming TANG ${ }^{1}$, Huchang LIAO $^{1}$, Víctor YEPES ${ }^{2}$, \\ Alfredas LAURINAVIČIUS ${ }^{3}$, Laura TUPE்NAITÉ ${ }^{4}$ \\ ${ }^{1}$ Business School, Sichuan University, 610064 Chengdu, China \\ ${ }^{2}$ Institute of Concrete Science and Technology (ICITECH), Universitat Politecnica de Valencia, \\ 46022 Valencia, Spain \\ ${ }^{3}$ Department of Roads, Vilnius Gediminas Technical University, Sauletekio al. 11, 10223 Vilnius, Lithuania \\ ${ }^{4}$ Department of Construction Management and Real Estate, Vilnius Gediminas Technical University, \\ Sauletekio al. 11, 10223 Vilnius, Lithuania
}

Received 14 November 2020; accepted 20 January 2021

\begin{abstract}
Automation in Construction is one of the leading international journals in construction and building dating back to 1992. This study aims to quantify and visualize the evolution of Automation in Construction publications using bibliometric methods. Our work has two parts: 1) publication and citation statistics in terms of annual distributions, citing sources, prolific countries/regions and institutes, and highly cited papers, 2) network and science mapping analyses in terms of co-authorship network, co-citation network and thematic evolution. Two bibliometric software, VOSviewer and SciMAT, are used to help us carry out the analyses. The results suggest that Automation in Construction has obtained increasing influence and reputation from scientific community over the past decades. It is expected that our study has guiding significance for editors and readers of this journal through providing key insights about the evolution over time.
\end{abstract}

Keywords: Automation in Construction, bibliometric, publications and citations, science mapping analyses, thematic evolution.

\section{Introduction}

In the early 1990s, the building industry was on the point of a major opportunity to use modern technology, and was asked to provide facilities to house, care, and feed for people to expand and modernize industries, and create novel capabilities. With the intention to assist in this endeavor, the Automation in Construction (AutCon) journal was established in 1992. According to three identified functional areas, namely, Architecture and Engineering, Construction Technologies, and Maintenance and Management, the journal aimed to represent novel and exciting possibilities regarding information technologies at each stage in the life cycle of a construction project. The editorial board also reflected the distinction of different stages. Three editors managed two areas for the first three years (1992-1995): Dr. Kansel for Construction Technologies, and Prof. Wagter and Smelter for Architecture and Engineering. In 1995, Prof. Skibniewski and Prof. Kalay took over two areas and served in the position for 12 years
(1995-2007). At the end of 2007, Prof. Skibniewski became the Editor-in-Chief. During the leadership of successive Editorial Boards, AutCon has experienced considerable developments and has become one of the leading journals in the field of construction and building. According to the 2019 Journal Citation Reports (JCR), the Impact Factor (IF) of AutCon is 5.669 and ranks the 8th out of 63 journals in "Construction \& Building Technology" and 7th out of 132 journals in "Engineering, Civil".

After the first issue, AutCon has contributed nearly 3000 publications up to 2019. It is necessary to review and summarize papers of this leading journal in the civil engineering field through exploring the development skeleton and evolvement. Several methods can be used to conduct a review such as traditional reviews (Navarro et al., 2020), bibliometric (Tang et al., 2020) and main path analysis (Yu \& Pan, 2021; Yu \& Sheng, 2020). Bibliometrics refers to the field of studying the characteristics of bibliographic

*Corresponding author. E-mail: liaohuchang@163.com

Copyright $\odot 2021$ The Author(s). Published by Vilnius Gediminas Technical University

This is an Open Access article distributed under the terms of the Creative Commons Attribution License (http://creativecommons.org/licenses/by/4.0/), which permits unrestricted use, distribution, and reproduction in any medium, provided the original author and source are credited. 
materials using quantitative and visualization tools (Tang et al., 2020). It detects prolific countries/regions, institutes and authors, research themes, and deduces patterns over time (Singh et al., 2020a). The research object of a bibliometric study can be a discipline (Liao et al., 2019), a journal (Singh et al., 2020b; Yu et al., 2019; Zhou et al., 2019), an institute (Dees, 2015) or even an author (Hartley, 2019). Bibliometrics plays a critical role in assessing and analyzing the research developed by different actors. For a specific journal, a bibliometric study can identify its developments and evolution status, so as to provide insights for future developments. In the field of civil engineering, bibliometric methods have been increasingly used (Canas-Guerrero et al., 2013, 2014; Cobo et al., 2014; Hosseini et al., 2018; Modak et al., 2019; Vilutiene et al., 2019b; Morkūnaitè et al., 2019; Derbe et al., 2020; Wang et al., 2020a). Some journals in the civil engineering field have also been analyzed using bibliometric methods such as Transportation Research journals (Modak et al., 2019), Journal of Civil Engineering and Management (Yu et al., 2019), and Computer-Aided Civil and Infrastructure Engineering (Wang et al., 2020b). These bibliometric studies can provide a dynamic perspective to obtain an insight for the developments of a specific journal or the civil engineering field.

To comprehensively identify influential countries/ regions, institutes, papers, and research topics from an evolving perspective, as well as encourage the scientific community in the journal field to engage further discussions, this study aims to conduct a bibliometric overview for AutCon publications from two perspectives: 1) publication and citation statistics in terms of annual distributions, sources citing AutCon publications, prolific countries/regions and institutes, and highly cited papers, 2) network and science mapping analyses in terms of coauthorship network for institutes and countries/regions, journal co-citation network and thematic evolution. Publication and citation statistics are implemented based on the Web of Science (WoS) database, one of the most widely used tool for generating citation data for research (Meho \& Yang, 2007). Regarding network and science mapping analyses, we mainly use two software: VOSviewer and SciMAT. VOSviewer has good performance in visualizing academic social network such as co-word, co-citation and co-authorship networks (Bornmann \& Haunschild, 2016). SciMAT can be used to identify the evolution of themes and find promising research directions. Our bibliometric work can help editors and researchers in this field know the past and current status of AutCon. Furthermore, it is hoped that our study can provide a reference for the evolution and future developments of the journal.

This rest of this bibliometric study is organized as follows: Section 1 describes the methodology. Section 2 presents basic publication and citation statistics. In Section 3, we provide network and science mapping analysis. Concluding remarks are given at the end of the study.

\section{Methodology and related work}

In this section, we describe the data used in this study and provide explanations about corresponding methods and software.

\subsection{Data}

This study focuses on AutCon studies published from 1992 to 2019 in the WoS Core Collection database and Inspec (Information service in physics, electro-technology, computer and control) database. Note that the publications from 1992-1999 were only covered in the Inspec database. Our work does not include the publications in 2020 since the volumes in 2020 have not been indexed completely by the WoS. The search query was built as: " $\mathrm{SO}=$ Automation in Construction NOT PY $=2020$ ". There are 2896 publications altogether. This number reduces to 2837 if we only consider articles (2816), proceedings papers (272) and reviews (121). Note that some publications were labeled as more than one document type simultaneously. All these records were exported in the format of plain text as the data source of bibliometric software. Note that publications from the Chinese mainland and Hong Kong are grouped under the China heading; publications from England, Scotland, Wales, and North Ireland are grouped under the UK (United Kingdom) heading. The solution is feasible as explained above.

\subsection{Methods}

To carry out publication and citation statistics, some indicators are used in this study, such as the total number of publications, total number of citations, average citations, and $h$-index (Hirsch, 2005). The $h$-index is an indicator to evaluate the research output of a scholar. A scholar has an $h$-index value of $h$ if $h$ of his/her $N$ papers receive at least $h$ citations and other $N$ - $h$ papers have less than $h$ citations.

There are different kinds of academic social networks, such as the co-authorship network, citation network, cocitation network, and bibliographic coupling network (Kong et al., 2019). In this study, we use the co-authorship network and co-citation network. Since collaboration has become more and more popular in various disciplines, the co-authorship network is one of the most widely-used academic social network (Kong et al., 2019). In a co-authorship network, a node can be an author, an institute or a country/region, and an edge connecting two nodes refers to a collaboration relationship. CO-citation refers the relation of two publications that are cited together by another publication (Singh et al., 2020b). If two publications are frequently cited by other publications, then these two publications have similarities more or less. Researchers have used co-citation network analysis to detect new insights of research trends (Upham \& Small, 2010; Rossetto et al., 2018). 


\subsection{Software}

Different bibliometric software tools have been developed. A summary of 9 main software tools is provided in Table 1 (Cobo et al., 2011b).

VOSviewer (n.d., https://www.vosviewer.com/) is a bibliometric software for a Java environment developed by van Eck and Waltman (2010). Using VOSviewer, the coauthorship network, co-citation network and co-occurrence network can be displayed intuitively. In this study, we employ VOSviewer to conduct the co-authorship analysis and co-citation analysis.

SciMAT (Cobo et al., 2012) is a science mapping analysis software developed by the University of Granada. SciMAT has three modules: 1) a module responsible for managing the knowledge base and its entities, 2) a module dedicated to the implementation of science mapping analysis, and 3) a module to visualize the generated results. In this study, we use SciMAT to generate strategic diagrams and evolution map. Using SciMAT to analyze thematic areas, a four-stage process is required (Cobo et al., 2012):

1) Detect corresponding research themes treated by the research area applying a co-word analysis for each period.

2) Layout in a low dimensional space (strategic diagram) regarding the themes of the previous stage. Two characteristics are used to measure a theme: centrality and density. The former measures the degree of interaction of a network with other networks while the latter measures the internal strength of the network:

a) Motor themes in the upper-right quadrant are well developed and significant for the structuring of a research field.

b) Highly developed and isolated themes in the upper-left quadrant have well-developed internal ties but unimportant external ties. Hence, they are of marginal importance for a field.

c) Emerging or declining themes in the lower-left quadrant are unimportant and weakly-developed.

d) Basic and transversal themes in the lower-right quadrant are important and not well-developed.

3) Analyze the evolution of research themes through different investigated sub-periods, so as to mine

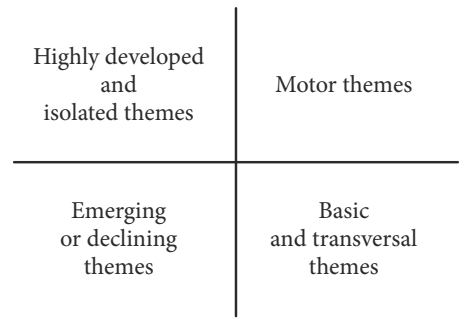

Figure 1. A strategic diagram

the thematic areas of a field, their origins and interrelationships.

4) Carry out a performance analysis for different subperiods, themes and thematic areas using impact and quantitative indicators.

In a strategic diagram, we can find four kinds of themes (see Figure 1).

Note that the data source of these two software is based on the WoS Core Collection database. Only the publications from 2000 of AutCon were collected by the Core Collection database. Therefore, network and science mapping analysis is based on the publications from 2000 to 2019. Publication and citation statistics include publications in all years.

\section{Publication and citation statistics}

Publication and citation statistics can identify the overall structure of a journal. In this section, we mainly present the publication and citation structures of AutCon publications in terms of annual distributions of publications and citations, citing sources, active countries/regions and institutes, and highly cited papers.

\subsection{Annual distributions of publications and citations}

The annual distribution of publications is shown in Figure 2. In the first four years (1992-1995), the annual numbers of publications were approximately 25. In 1996 and 1997, there was a growth because special issues were added. Between 1998 and 2011, the annual numbers of publications in AutCon presented a steady uptrend year by year. In this period, a calendar year usually published one volume

Table 1. A comparison of main bibliometric tools

\begin{tabular}{|l|c|l|l|}
\hline \multicolumn{1}{|c|}{ Software tool } & Developed year & \multicolumn{1}{|c|}{ Developed by } & \multicolumn{1}{c|}{ Analysis type } \\
\hline IN-SPIRE & 1999 & Pacific Northwest National Laboratory & Bust detection, network, temporal \\
\hline CiteSpace & 2004 & Drexel University & Bust detection, geospatial, network, temporal \\
\hline VantagePoint & 2004 & Search Technology, Inc. & Bust detection, geospatial, network, temporal \\
\hline CoPalRed & 2005 & University of Granada & Network, temporal \\
\hline Bibexcel & 2009 & University of Umeå & Network \\
\hline Sci ${ }^{2}$ Tool & 2009 & Indiana University & Bust detection, geospatial, network, temporal \\
\hline VOSViewer & 2010 & Leiden University & Network \\
\hline SciMAT & 2012 & University of Granada & Network, temporal \\
\hline
\end{tabular}


including 5-8 issues. In 2012, the journal changed this pattern and published 8 volumes each year. This number increased to 12 in 2014 and continued until this year. In the last two years, the number of publications had a considerable growth, with the highest number of 315 in 2018.
Regarding citation counts, AutCon has a good performance. Table 2 presents the annual publication and citation structure in AutCon. Table 2 illustrates that $3.10 \%$ of all publications received more than 100 citations, $12.62 \%$ more than 50 , and $58.51 \%$ more than 10 . Only about $5 \%$

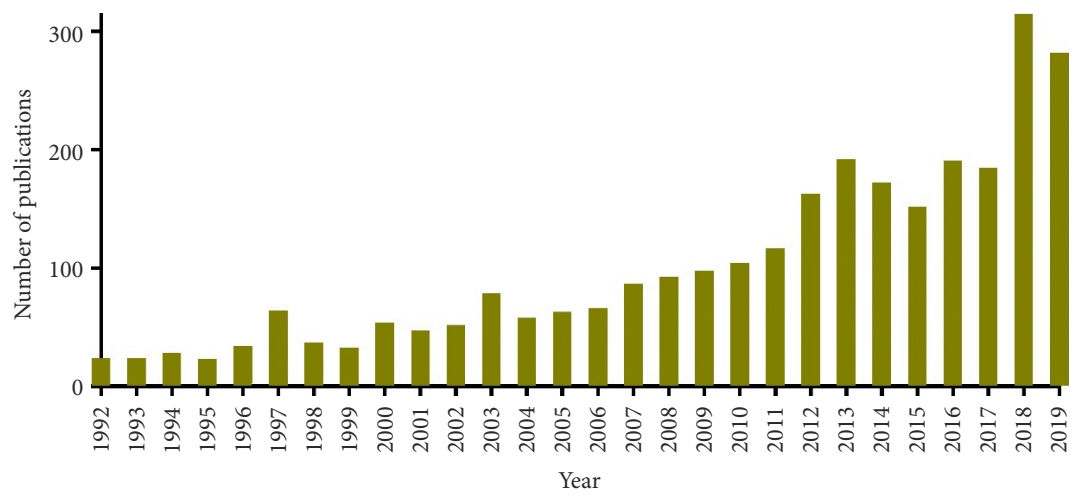

Figure 2. The distribution of publications by year

Table 2. Annual publication and citation structure in AutCon according to the WoS

\begin{tabular}{|c|c|c|c|c|c|c|c|c|c|c|c|}
\hline Year & $\geq 100$ & $\geq 50$ & $\geq 20$ & $\geq 10$ & $\geq 1$ & TD & TCD & $\mathrm{AC}$ & TCY & $h$-index & IF \\
\hline 1992 & 0 & 0 & 3 & 4 & 19 & 24 & 166 & 6.92 & 0 & 6 & - \\
\hline 1993 & 0 & 0 & 0 & 2 & 19 & 24 & 75 & 3.13 & 0 & 5 & - \\
\hline 1994 & 0 & 0 & 0 & 3 & 20 & 28 & 90 & 3.21 & 7 & 6 & - \\
\hline 1995 & 0 & 0 & 1 & 5 & 20 & 23 & 131 & 5.7 & 6 & 6 & - \\
\hline 1996 & 0 & 0 & 2 & 8 & 28 & 34 & 200 & 5.88 & 20 & 9 & - \\
\hline 1997 & 0 & 2 & 9 & 15 & 50 & 64 & 564 & 8.81 & 13 & 13 & - \\
\hline 1998 & 0 & 2 & 7 & 16 & 33 & 37 & 471 & 12.73 & 30 & 14 & - \\
\hline 1999 & 0 & 2 & 12 & 17 & 31 & 33 & 533 & 16.15 & 24 & 14 & - \\
\hline 2000 & 1 & 10 & 21 & 35 & 52 & 54 & 1398 & 25.89 & 56 & 20 & - \\
\hline 2001 & 0 & 2 & 12 & 21 & 44 & 47 & 666 & 14.17 & 94 & 14 & - \\
\hline 2002 & 1 & 11 & 29 & 37 & 50 & 52 & 1477 & 28.4 & 95 & 24 & 0.312 \\
\hline 2003 & 0 & 7 & 19 & 35 & 58 & 79 & 1280 & 16.2 & 167 & 19 & 0.320 \\
\hline 2004 & 4 & 13 & 31 & 43 & 57 & 58 & 2008 & 34.62 & 218 & 26 & 0.360 \\
\hline 2005 & 4 & 12 & 35 & 47 & 63 & 63 & 2162 & 34.32 & 347 & 28 & 0.387 \\
\hline 2006 & 7 & 19 & 38 & 52 & 65 & 66 & 2547 & 38.59 & 527 & 32 & 0.792 \\
\hline 2007 & 6 & 20 & 47 & 71 & 87 & 87 & 3168 & 36.41 & 691 & 34 & 0.609 \\
\hline 2008 & 7 & 21 & 54 & 77 & 92 & 93 & 3324 & 35.74 & 1067 & 33 & 1.664 \\
\hline 2009 & 8 & 26 & 60 & 85 & 97 & 98 & 4247 & 43.34 & 1296 & 37 & 1.372 \\
\hline 2010 & 9 & 30 & 56 & 89 & 103 & 104 & 4560 & 43.85 & 1387 & 40 & 1.311 \\
\hline 2011 & 7 & 33 & 73 & 93 & 115 & 117 & 4527 & 38.69 & 1720 & 39 & 1.500 \\
\hline 2012 & 8 & 26 & 81 & 122 & 160 & 163 & 4998 & 30.66 & 2475 & 39 & 1.820 \\
\hline 2013 & 11 & 39 & 103 & 149 & 191 & 192 & 6550 & 34.11 & 3217 & 44 & 1.822 \\
\hline 2014 & 8 & 27 & 84 & 135 & 172 & 172 & 5721 & 33.26 & 4107 & 39 & 1.812 \\
\hline 2015 & 6 & 28 & 76 & 120 & 151 & 152 & 4383 & 28.84 & 5346 & 37 & 2.442 \\
\hline 2016 & 1 & 14 & 73 & 125 & 188 & 191 & 3727 & 19.51 & 6108 & 32 & 2.919 \\
\hline 2017 & 0 & 10 & 55 & 109 & 179 & 185 & 3130 & 16.92 & 7609 & 30 & 4.032 \\
\hline 2018 & 0 & 4 & 43 & 119 & 300 & 315 & 3242 & 10.29 & 10159 & 25 & 4.313 \\
\hline 2019 & 0 & 0 & 5 & 26 & 243 & 282 & 1143 & 4.05 & 12628 & 13 & 5.669 \\
\hline Total & 88 & 358 & 1029 & 1660 & 2687 & 2837 & 66488 & 23.44 & 66488 & 96 & \\
\hline Percentage & $3.10 \%$ & $12.62 \%$ & $36.27 \%$ & $58.51 \%$ & $94.71 \%$ & & & & & & \\
\hline
\end{tabular}

Notes: TD - Total documents; TCD - Total citations for documents published in a particular year; AC - Average number of citations by year; TCY - Total citations in that year; IF - Impact Factor. 
of publications did not obtain any citation. The average number of citations (AC) for AutCon documents is 23.44. In 2000, there is a leap regarding the value of $\mathrm{AC}$. The AC achieved its peak in 2010. In the following decade, the value of $\mathrm{AC}$ has a downward trend, which is a normal phenomenon since a paper needs 3 to 7 years to achieve its majority of citations (Wang, 2013). The number of received citations has increased significantly in the last years (see TCY) because of the powerful worldwide expansion of research. Until 2002, the annual received citations were less than 100. During the last two years, the TCY overcame a threshold 10000. This suggested that AutCon has obtained increasing reputation in scientific community. The IF can also prove this. In 2002, AutCon had an IF of 0.312 . During the following several years, the IF remained stable, and started to increase in 2006. In 2008, the IF overcame a threshold 1 and kept at this level until 2014. In 2019, ActCon obtained a record of 5.669.

\subsection{Sources citing AutCon publications}

Analyzing the sources that cite AutCon publications is another interesting topic since it can know who are paying attention to the journal. Table 3 displays the top 30 journals, institutes and countries/regions that have papers citing AutCon publications. As the data shown in Table 3, AutCon itself is the journal with the highest number of studies citing AutCon publications. It is a common phenomenon that a journal cites itself (Tang et al., 2020) and it is logical since the material appeared in AutCon tends to influence future researches in the same journal. Journal of Construction Engineering and Management, Energy Buildings and Journal of Computing in Civil Engineering cite AutCon publications frequently, with 614, 476, and 467 publications, respectively. In general, construction \& building journals are those that cited more AutCon documents.

Regarding institutes, the Hong Kong Polytechnic University is in the leading position, with over 700 studies citing AutCon, followed by the Tsinghua University, Tongji University and Georgia Institute of Technology. Note that two thirds of these 30 institutes come from Asia, particularly from China. Therefore, regarding countries, China is unsurprisingly the country that cites AutCon most, followed by the USA and the UK. Some small countries also have a good performance and appear in Table 3, such as Lithuania and Vietnam.

Table 3. Number of studies citing AutCon

\begin{tabular}{|c|c|c|c|c|c|c|}
\hline $\mathrm{R}$ & Journal & TS & Institute & TS & $\begin{array}{l}\text { Country/ } \\
\text { region }\end{array}$ & TS \\
\hline 1 & Automation in Construction & 2062 & Hong Kong Polytechnic University & 767 & China & 7258 \\
\hline 2 & $\begin{array}{l}\text { Journal of Construction Engineering } \\
\text { and Management }\end{array}$ & 614 & Tsinghua University & 358 & USA & 4760 \\
\hline 3 & Energy and Buildings & 476 & Tongji University & 351 & UK & 2137 \\
\hline 4 & $\begin{array}{l}\text { Journal of Computing in Civil } \\
\text { Engineering }\end{array}$ & 467 & Georgia Institute of Technology & 342 & Australia & 1854 \\
\hline 5 & Sustainability & 399 & Curtin University & 297 & South Korea & 1575 \\
\hline 6 & Journal of Cleaner Production & 344 & $\begin{array}{l}\text { Huazhong University of Science and } \\
\text { Technology }\end{array}$ & 273 & Canada & 1258 \\
\hline 7 & Advanced Engineering Informatics & 307 & National University of Singapore & 271 & Taiwan & 1198 \\
\hline 8 & Procedia Engineering & 303 & Vilnius Gediminas Technical University & 262 & Spain & 1156 \\
\hline 9 & Sensors & 300 & City University of Hong Kong & 258 & Italy & 1030 \\
\hline 10 & Building and Environment & 281 & $\begin{array}{l}\text { National Taiwan University of Science and } \\
\text { Technology }\end{array}$ & 254 & Iran & 993 \\
\hline 11 & $\begin{array}{l}\text { Journal of Civil Engineering and } \\
\text { Management }\end{array}$ & 269 & Islamic Azad University & 251 & Turkey & 812 \\
\hline 12 & Journal of Management in Engineering & 248 & Zhejiang University & 239 & Germany & 806 \\
\hline 13 & $\begin{array}{l}\text { Engineering Construction and } \\
\text { Architectural Management }\end{array}$ & 240 & University of Alberta & 238 & Malaysia & 798 \\
\hline 14 & Construction and Building Materials & 231 & Harbin Institute of Technology & 237 & Poland & 682 \\
\hline 15 & IEEE Access & 212 & Centre National de la Recherche Scientifique & 232 & France & 673 \\
\hline 16 & Lecture Notes in Computer Science & 212 & Purdue University & 232 & India & 596 \\
\hline 17 & Applied Sciences Basel & 208 & Chongqing University & 231 & Netherlands & 534 \\
\hline 18 & Expert Systems with Applications & 170 & Tianjin University & 219 & Singapore & 523 \\
\hline 19 & KSCE Journal of Civil Engineering & 166 & University of New South Wales Sydney & 219 & Portugal & 503 \\
\hline 20 & Applied Energy & 163 & Queensland University of Technology & 213 & Brazil & 483 \\
\hline 21 & Safety Science & 161 & Universiti Teknologi Malaysia & 207 & Japan & 454 \\
\hline
\end{tabular}


End of Table 3

\begin{tabular}{|c|c|c|c|c|c|c|}
\hline $\mathrm{R}$ & Journal & TS & Institute & TS & $\begin{array}{l}\text { Country/ } \\
\text { region }\end{array}$ & TS \\
\hline 22 & $\begin{array}{l}\text { International Journal of Project } \\
\text { Management }\end{array}$ & 148 & Dalian University of Technology & 204 & Sweden & 365 \\
\hline 23 & $\begin{array}{l}\text { Computer-Aided Civil and } \\
\text { Infrastructure Engineering }\end{array}$ & 144 & Yonsei University & 200 & Switzerland & 337 \\
\hline 24 & Energies & 139 & Polytechnic University of Milan & 197 & Lithuania & 307 \\
\hline 25 & Applied Mechanics and Materials & 137 & Southeast University (China) & 196 & Finland & 291 \\
\hline 26 & $\begin{array}{l}\text { International Journal of Construction } \\
\text { Management }\end{array}$ & 135 & Delft University of Technology & 195 & Greece & 288 \\
\hline 27 & Renewable Sustainable Energy Reviews & 125 & University of Hong Kong & 193 & Belgium & 264 \\
\hline 28 & Remote Sensing & 123 & Chinese Academy of Sciences & 189 & Saudi Arabia & 243 \\
\hline 29 & $\begin{array}{l}\text { Journal of } \\
\text { Building Engineering }\end{array}$ & 122 & Hanyang University & 184 & Egypt & 223 \\
\hline 30 & $\begin{array}{l}\text { Journal of Information Technology in } \\
\text { Construction }\end{array}$ & 112 & Concordia University & 183 & Vietnam & 200 \\
\hline
\end{tabular}

Note: TS - Total studies.

\subsection{Prolific countries/regions and institutes}

AutCon is an international journal and thus researchers from countries across the globe have published in this journal. Up to now, 73 countries have contributed papers to AutCon. Table 4 presents the top 30 prolific countries/ regions in AutCon. Note that in our study, the country/ region refers that where an author is working at the moment of publication. As we can see from Table 4, the USA exhibits its predominance in TD and TC with 722 publications and 19640 citations, followed by China, the UK and South Korea. Australia obtains the sixth position and shows a high productivity per inhabitant. In Table 4 , there are 16 European countries, 9 Asian countries/regions, 2 North American countries, 2 Oceania countries and 1 African country. Therefore, developing countries from Africa and South America still have a long way to go. Some small countries with a population of less than 5 million also appear in Table 4, such as New Zealand, Slovenia and Ireland. If we normalize TD and TC against population, those developed countries/regions with small sized population showed their advantages, such as Taiwan, Australia, Israel and Finland. Several developing counties/regions are also on the list, such as China, Iran, Turkey, Egypt, and Malaysia. With the development of scientific activities in these developing countries/regions, especially Asian countries, it is expected that the number of publications from these countries/regions will increase in the future.

Regarding institutes, Table 5 presents the most active institutes with additional indicators such as the TD, TC, $\mathrm{AC}, h$-index and number of documents reaching the citation threshold 100, 50, and 20, respectively. Furthermore, we also provide the world ranks of these institutes according to the Academic Ranking of World Universities (ARWU) and the Quacquarelli Symonds (QS) World University Rankings. The objective is to show that researchers from top institutes across the globe have contributed publications in AutCon. As we can see from Table 5, among these 30 institutes, seven are from China, six are from the
USA, and four are from South Korea. The Hong Kong Polytechnic University is in the leading position with 162 publications and 4946 citations, followed by the Georgia University of Technology and National Taiwan University of Science and Technology. Note that the Carnegie Mellon University has the best performance regarding the AC, which suggests that the publications from this university have significant influence. We can find that several institutes are not in the top 500 according to ARWU and QS rankings, such as Concordia University and University of Salford. Hence, from this perspective, AutCon is diverse and has influence not only in leading universities over the world.

\subsection{Highly cited papers}

Since its establishment, AutCon has contributed many highly influential papers to construction and building research. The top 10 highly cited papers are analyzed in detail.

Table 6 lists the top 10 most cited papers of all time appeared in AutCon according to the WoS. Additional indicators for the top 10 highly cited papers are also provided, such as the number of institutes (NI), number of countries/regions $(\mathrm{NC} / \mathrm{R})$ finishing the paper, document type (DY) and citations/year (C/Y).

The most cited paper was written by Volk et al. (2014) with 556 citations. This study provided a state-of-the-art review of building information modeling implementation and research in existing buildings based on 180 publications. According to the ISO 29481-1:2010(E) standard (International Organization for Standardization, 2010) and Vilutiene et al. (2019a), the building information modeling can be defined as " $a$ shared digital representation of physical and functional characteristics of any built object which forms a reliable basis for decisions". Furthermore, this paper is also one of the latest papers among top 10 highly cited papers (published in 2014). Hence, it is expected that this review will receive more citations in the future. 
Table 4. The top 30 prolific countries/regions

\begin{tabular}{|c|c|c|c|c|c|c|c|c|c|c|c|}
\hline Rank & Country/region & TD & $\mathrm{TC}$ & $\mathrm{AC}$ & $h$-index & Pop & TD/Pop & TC/Pop & $\geq 100$ & $\geq 50$ & $\geq 20$ \\
\hline 1 & USA & 722 & 19640 & 27.20 & 67 & 326,767 & 2.21 & 60.25 & 32 & 112 & 295 \\
\hline 2 & China & 552 & 13273 & 24.05 & 60 & $1,400,050$ & 0.39 & 9.48 & 19 & 84 & 209 \\
\hline 3 & UK & 292 & 7622 & 26.10 & 47 & 66,573 & 4.39 & 114.49 & 14 & 46 & 114 \\
\hline 4 & South Korea & 270 & 6736 & 24.95 & 42 & 51,269 & 5.27 & 131.39 & 10 & 37 & 105 \\
\hline 5 & Taiwan & 245 & 5677 & 23.17 & 41 & 23,694 & 10.34 & 239.60 & 3 & 27 & 102 \\
\hline 6 & Australia & 209 & 6377 & 30.51 & 43 & 24,772 & 8.44 & 257.43 & 8 & 40 & 94 \\
\hline 7 & Canada & 185 & 4460 & 24.11 & 37 & 36,954 & 5.01 & 120.70 & 7 & 23 & 68 \\
\hline 8 & Spain & 92 & 1990 & 21.63 & 25 & 46,397 & 1.98 & 42.89 & 2 & 7 & 33 \\
\hline 9 & Netherlands & 71 & 981 & 13.82 & 17 & 17,084 & 4.16 & 57.42 & 1 & 3 & 12 \\
\hline 10 & Germany & 69 & 1982 & 28.00 & 20 & 82,293 & 0.84 & 24.08 & 2 & 7 & 20 \\
\hline 11 & Singapore & 66 & 1402 & 21.24 & 20 & 5,791 & 11.40 & 242.06 & 2 & 8 & 20 \\
\hline 12 & Israel & 60 & 1684 & 28.07 & 20 & 8,453 & 7.10 & 237.18 & 5 & 12 & 21 \\
\hline 13 & Poland & 60 & 758 & 12.63 & 15 & 38,104 & 1.57 & 19.89 & 0 & 2 & 11 \\
\hline 14 & Japan & 59 & 840 & 14.24 & 16 & 127,185 & 0.46 & 6.60 & 0 & 4 & 14 \\
\hline 15 & Italy & 55 & 787 & 14.31 & 15 & 60,482 & 0.91 & 13.01 & 0 & 2 & 13 \\
\hline 16 & Portugal & 46 & 1104 & 24.00 & 18 & 10,291 & 4.47 & 107.28 & 1 & 6 & 16 \\
\hline 17 & France & 42 & 876 & 20.86 & 15 & 65,233 & 0.64 & 13.40 & 2 & 3 & 14 \\
\hline 18 & Finland & 37 & 836 & 22.59 & 14 & 5,542 & 6.68 & 150.85 & 2 & 6 & 12 \\
\hline 19 & Iran & 35 & 524 & 14.97 & 13 & 82,012 & 0.43 & 6.39 & 0 & 2 & 9 \\
\hline 20 & Turkey & 34 & 903 & 26.56 & 17 & 81,917 & 0.42 & 11.02 & 1 & 6 & 16 \\
\hline 21 & Switzerland & 31 & 603 & 19.45 & 11 & 8,544 & 3.63 & 70.58 & 1 & 3 & 6 \\
\hline 22 & Egypt & 29 & 577 & 19.90 & 13 & 99,376 & 0.29 & 5.81 & 0 & 4 & 10 \\
\hline 23 & Sweden & 26 & 527 & 20.27 & 12 & 9,983 & 2.60 & 26.00 & 0 & 3 & 10 \\
\hline 24 & Belgium & 22 & 495 & 22.50 & 12 & 11,498 & 1.91 & 43.05 & 0 & 3 & 8 \\
\hline 25 & Malaysia & 19 & 344 & 18.11 & 10 & 32,042 & 0.59 & 10.74 & 0 & 1 & 6 \\
\hline 26 & New Zealand & 18 & 321 & 17.83 & 8 & 4,749 & 3.79 & 67.59 & 0 & 3 & 4 \\
\hline 27 & Slovenia & 18 & 278 & 15.44 & 10 & 2,081 & 8.65 & 133.59 & 0 & 1 & 5 \\
\hline 28 & Austria & 15 & 102 & 6.80 & 6 & 8,751 & 1.71 & 11.66 & 0 & 0 & 2 \\
\hline 29 & Ireland & 15 & 292 & 19.47 & 8 & 4,804 & 3.12 & 60.78 & 1 & 1 & 4 \\
\hline 30 & Greece & 14 & 229 & 16.36 & 9 & 11,142 & 1.26 & 20.55 & 0 & 0 & 5 \\
\hline
\end{tabular}

Notes: TD - Total documents; TC - Total citations; AC - Average number of citations; Pop - Population in thousands; TD/Pop - Total documents by person multiplied by one million; TC/Pop - Total citations by person multiplied by one million.

Table 5. Top 30 prolific institutes

\begin{tabular}{|c|l|c|c|c|c|c|c|c|c|c|c|}
\hline Rank & \multicolumn{1}{|c|}{ Institute } & TD & TC & AC & $h$-index & $\geq 100$ & $\geq 50$ & $\geq 20$ & $\begin{array}{c}\text { Country/ } \\
\text { region }\end{array}$ & ARWU & QS \\
\hline 1 & $\begin{array}{l}\text { Hong Kong Polytechnic } \\
\text { University }\end{array}$ & 162 & 4946 & 30.53 & 42 & 6 & 34 & 80 & China & $201-300$ & 75 \\
\hline 2 & $\begin{array}{l}\text { Georgia University of } \\
\text { Technology }\end{array}$ & 85 & 4176 & 49.13 & 38 & 11 & 26 & 53 & USA & $101-150$ & 80 \\
\hline 3 & $\begin{array}{l}\text { National Taiwan University } \\
\text { of Science and Technology }\end{array}$ & 72 & 1783 & 24.76 & 25 & 1 & 6 & 34 & Taiwan & $901-1000$ & 267 \\
\hline 4 & Tsinghua University & 70 & 1951 & 27.87 & 24 & 4 & 13 & 27 & China & 43 & 15 \\
\hline 5 & $\begin{array}{l}\text { Huazhong University of } \\
\text { Science and Technology }\end{array}$ & 54 & 1259 & 23.31 & 19 & 2 & 8 & 19 & China & $101-150$ & 396 \\
\hline 6 & $\begin{array}{l}\text { City University of } \\
\text { Hong Kong }\end{array}$ & 52 & 1173 & 22.56 & 19 & 1 & 8 & 19 & China & $201-300$ & 48 \\
\hline 7 & Curtin University & 52 & 1628 & 31.31 & 23 & 4 & 12 & 26 & Australia & $201-300$ & 217 \\
\hline 8 & National Taiwan University & 49 & 1108 & 22.61 & 18 & 1 & 7 & 18 & Taiwan & $151-200$ & 66 \\
\hline 9 & University of Alberta & 48 & 684 & 14.25 & 15 & 0 & 2 & 10 & Canada & $101-150$ & 119 \\
\hline 10 & Concordia University & 46 & 938 & 20.39 & 17 & 1 & 5 & 12 & Canada & $801-900$ & 477 \\
\hline
\end{tabular}


End of Table 5

\begin{tabular}{|c|c|c|c|c|c|c|c|c|c|c|c|}
\hline Rank & Institute & $\mathrm{TD}$ & TC & $\mathrm{AC}$ & $h$-index & $\geq 100$ & $\geq 50$ & $\geq 20$ & $\begin{array}{l}\text { Country/ } \\
\text { region }\end{array}$ & ARWU & QS \\
\hline 11 & Yonsei University & 41 & 911 & 22.22 & 17 & 0 & 8 & 15 & South Korea & $201-300$ & 85 \\
\hline 12 & Kyung Hee University & 40 & 1299 & 32.48 & 20 & 3 & 7 & 20 & South Korea & $301-400$ & 236 \\
\hline 13 & University of Michigan & 38 & 1031 & 27.13 & 17 & 3 & 5 & 15 & USA & 20 & 21 \\
\hline 14 & Loughborough University & 36 & 1610 & 44.72 & 23 & 2 & 12 & 25 & UK & $701-800$ & 226 \\
\hline 15 & $\begin{array}{l}\text { The University of Hong } \\
\text { Kong }\end{array}$ & 36 & 1110 & 30.83 & 18 & 2 & 7 & 16 & China & $101-150$ & 22 \\
\hline 16 & $\begin{array}{l}\text { University of Illinois at } \\
\text { Urbana-Champaign }\end{array}$ & 36 & 1087 & 30.19 & 20 & 1 & 9 & 20 & USA & 38 & 82 \\
\hline 17 & Hanyang University & 35 & 935 & 26.71 & 14 & 2 & 3 & 10 & South Korea & $301-400$ & 146 \\
\hline 18 & $\begin{array}{l}\text { National University of } \\
\text { Singapore }\end{array}$ & 33 & 523 & 15.85 & 14 & 0 & 2 & 8 & Singapore & 67 & 11 \\
\hline 19 & Purdue University & 33 & 756 & 22.91 & 16 & 1 & 2 & 12 & USA & 72 & 109 \\
\hline 20 & University of Waterloo & 33 & 1083 & 32.82 & 17 & 4 & 8 & 16 & Canada & $151-200$ & 166 \\
\hline 21 & Carnegie Mellon University & 32 & 1733 & 54.16 & 18 & 6 & 12 & 15 & USA & 95 & 51 \\
\hline 22 & Zhejiang University & 29 & 861 & 29.69 & 16 & 0 & 7 & 16 & China & 70 & 53 \\
\hline 23 & University of Salford & 28 & 1217 & 43.46 & 20 & 3 & 8 & 20 & UK & - & $801-1000$ \\
\hline 24 & $\begin{array}{l}\text { University of Texas at } \\
\text { Austin }\end{array}$ & 28 & 812 & 29.00 & 16 & 1 & 6 & 11 & USA & 45 & 71 \\
\hline 25 & $\begin{array}{l}\text { Queensland University of } \\
\text { Technology }\end{array}$ & 27 & 862 & 31.93 & 17 & 1 & 7 & 13 & Australia & $301-400$ & 217 \\
\hline 26 & $\begin{array}{l}\text { National Chiao Tung } \\
\text { University }\end{array}$ & 26 & 545 & 20.96 & 13 & 0 & 2 & 9 & Taiwan & $501-600$ & 240 \\
\hline 27 & Seoul National University & 26 & 364 & 14.00 & 12 & 0 & 1 & 6 & South Korea & $101-150$ & 37 \\
\hline 28 & $\begin{array}{l}\text { Israel Institute of } \\
\text { Technology }\end{array}$ & 26 & 1115 & 42.88 & 15 & 5 & 9 & 12 & Israel & 85 & 291 \\
\hline 29 & Tongji University & 26 & 428 & 16.46 & 10 & 0 & 3 & 5 & China & $201-300$ & 256 \\
\hline 30 & University of Lisbon & 26 & 546 & 21.00 & 13 & 0 & 3 & 8 & Portugal & $151-200$ & 357 \\
\hline
\end{tabular}

Notes: TD - Total documents; TC - Total citations; AC - Average number of citations; ARWU - Academic Ranking of World Universities; QS - Quacquarelli Symonds World University Rankings.

Table 6. The top 10 most cited documents in AutCon according to the WoS

\begin{tabular}{|c|c|c|c|c|c|c|}
\hline Rank & Title & $\mathrm{NI}$ & $\mathrm{NC} / \mathrm{R}$ & DY & Citations & $\mathrm{C} / \mathrm{Y}$ \\
\hline 1 & $\begin{array}{l}\text { Building Information Modeling (BIM) for existing buildings - literature review } \\
\text { and future needs (Volk et al., 2014) }\end{array}$ & 1 & 1 & Review & 556 & 79.43 \\
\hline 2 & $\begin{array}{l}\text { Building information modelling framework: A research and delivery foundation } \\
\text { for industry stakeholders (Succar, 2009) }\end{array}$ & 2 & 1 & Article & 480 & 40.00 \\
\hline 3 & $\begin{array}{l}\text { Automatic reconstruction of as-built building information models from laser- } \\
\text { scanned point clouds: A review of related techniques (Tang et al., 2010) }\end{array}$ & 4 & 1 & Review & 375 & 34.09 \\
\hline 4 & $\begin{array}{l}\text { The gap between predicted and measured energy performance of buildings: A } \\
\text { framework for investigation (de Wilde, 2014) }\end{array}$ & 2 & 1 & Article & 334 & 47.71 \\
\hline 5 & $\begin{array}{l}\text { Building information modeling (BIM) and safety: Automatic safety checking of } \\
\text { construction models and schedules (Zhang et al., 2013) }\end{array}$ & 3 & 2 & Article & 294 & 36.75 \\
\hline 6 & $\begin{array}{l}\text { Understanding and facilitating BIM adoption in the AEC industry (Gu \& } \\
\text { London, 2010) }\end{array}$ & 2 & 1 & Article & 288 & 26.18 \\
\hline 7 & $\begin{array}{l}\text { Mobile 3D mapping for surveying earthwork projects using an Unmanned } \\
\text { Aerial Vehicle (UAV) system (Siebert \& Teizer, 2014) }\end{array}$ & 2 & 2 & Article & 286 & 40.86 \\
\hline 8 & $\begin{array}{l}\text { Developments in construction-scale additive manufacturing processes (Lim } \\
\text { et al., 2012) }\end{array}$ & 1 & 1 & Article & 262 & 29.11 \\
\hline 9 & $\begin{array}{l}\text { Building information model based energy/exergy performance assessment in } \\
\text { early design stages (Schlueter \& Thesseling, 2009) }\end{array}$ & 1 & 1 & Article & 258 & 21.50 \\
\hline 10 & $\begin{array}{l}\text { Automatic creation of semantically rich 3D building models from laser scanner } \\
\text { data (Xiong et al., 2013) }\end{array}$ & 3 & 2 & Article & 252 & 31.50 \\
\hline
\end{tabular}

Notes: NI - Number of institutes; NC/R - Number of countries/regions; DY - Document type; C/Y - Citations/Year. 
The second most cited work was written by Succar (2009) and has received 480 citations. This paper also focused on building information modeling. It discussed some publicly available international guidelines and introduced the framework of building information modeling. Note that Tezizer Jochen has three publications in the list and four authors including Gu Ning, Huber Daniel, Akinci Burcu, and Lee Jin-Kook have two publications.

Among top 10 highly cited papers, only 3 were international collaboration papers. Hence, for influential studies of AutCon, the inter-country/region collaboration is not significant. Furthermore, 3 papers were finished by a single institute. Regarding the document type, 8 are articles and 2 are reviews. Although some literature (Miranda \& Garcia-Carpintero, 2018; Zahedi \& Haustein, 2018) suggested that review papers tend to obtain more citations than regular articles, reviews have few advantages in AutCon. 8 papers were published in the 2010s and the rest were published in the 2000s. Note that none publication in the last half decade was included. It is logical since a paper usually needs a period of 3 to 7 years to reach its majority of citations (Liao et al., 2019). Therefore, publications in recent years still need time to catch up.

\section{Network and science mapping analysis}

To know the collaboration status of AutCon publications, journals that are most related to AutCon, research topics and evolution of themes, this section carries out network and science mapping analyses for AutCon publications.

\subsection{The co-authorship network}

Since the last century, scientific collaboration has gradually become a mainstream scientific knowledge pattern in various fields (Kong et al., 2019). Because of the subject specialization, co-authorship is one of the most extensive and practical way of scientific collaboration (Tang et al., 2018; Liao et al., 2019; Zhou et al., 2020). This section presents the country/region co-authorship network and institute co-authorship network regarding AutCon publications.

To display the main structure of institute co-authorship network, all institutes are filtered by a minimum threshold of 9 publications in AutCon, which results in 99 institutes. Among them, some are not connected to each other. Finally, using the VOSviewer software package, the institute co-authorship network with 92 identified nodes is demonstrated in Figure 3. According to the clustering process embedded in VOSviewer, we obtain 16 clusters. The largest cluster in red color contains 24 items, mainly from South Korea. The Yonsei University, Kyung Hee University, Hanyang University and Seoul National University are active nodes in this cluster. In Figure 3, the biggest node is the Hong Kong Polytechnic University, which echoes the content of Table 5. The Hong Kong Polytechnic University has several major cooperative partners such as the Queensland University of Technology, Huazhong University of Science and Technology, Tsinghua University, City University of Hong Kong, and Curtin University, with a link strength of $14,12,13,10$, and 7 , respectively.

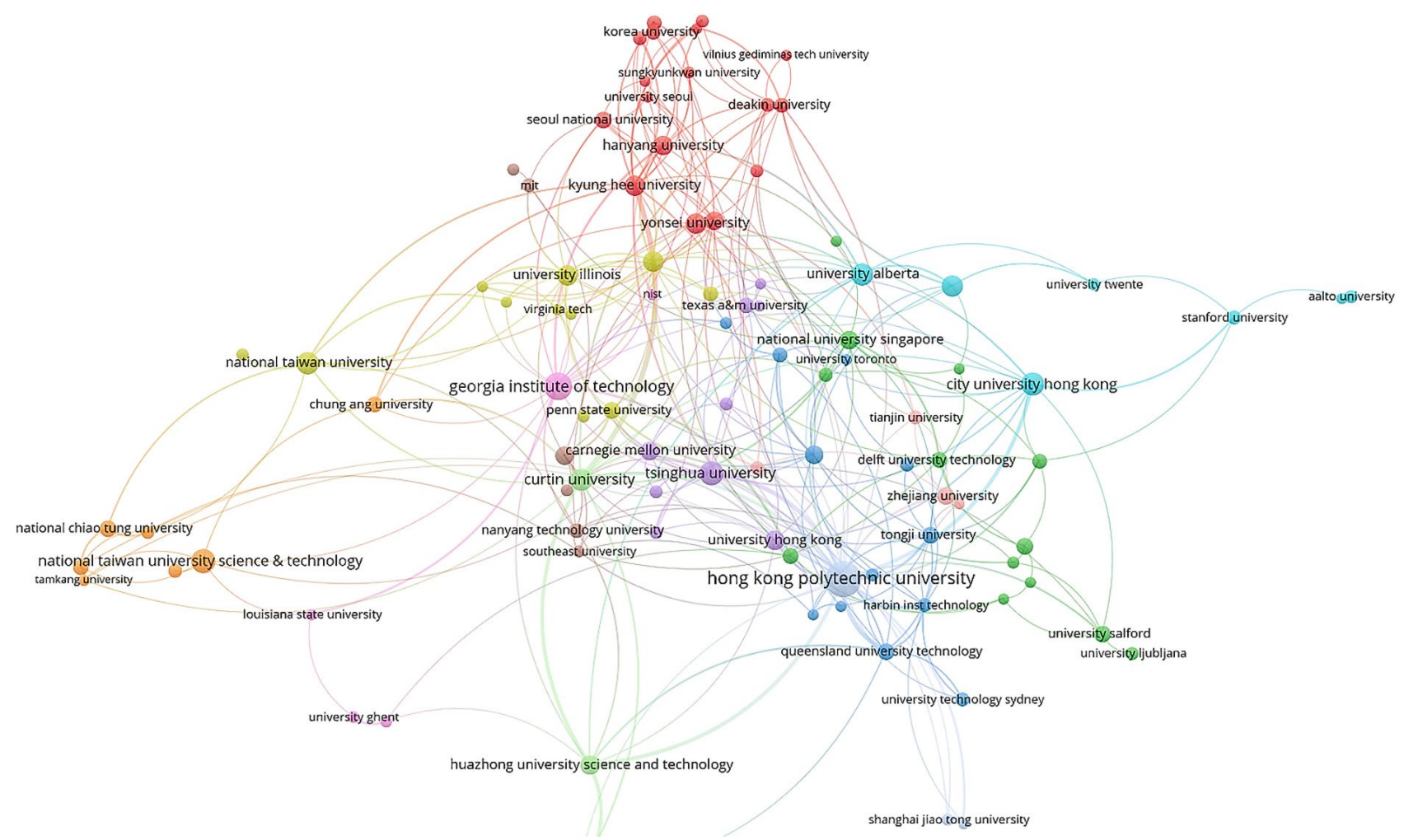

Figure 3. The institute co-authorship network 
The thickest line connects the Kyung Hee University and Curtin University, which suggests the deep collaborative relationship between these two universities.

We construct the country co-authorship network in Figure 4. The whole network has 69 nodes. However, Bahrain, Jordan, Serbia, Slovenia and South Africa did not have collaboration with other countries/regions. Therefore, Figure 4 consists of 64 nodes. As shown in Figure 4, the USA and China are two biggest nodes. The link strength of these two counties is 59. The thickest line is constructed by China and Australia. 76 papers were finished in the form of collaboration between these two countries. Main cooperative relationships include the Queensland University of Technology-Hong Kong Polytechnic University (14), Curtin University-Huazhong University of Science and Technology (13), and Curtin University-Hong Kong Polytechnic University (7). Two major partners of the USA are China and South Korea, and three major partners of China are Canada, the USA and the UK. This denotes that the geographical location is not the determining factor that influences international collaborations.

\subsection{The journal co-citation network}

To detect the relationships of AutCon with other journals, this section conducts the journal co-citation analysis. Journal co-citation analysis, as a branch of co-citation analysis, has been widely used to reveal the underlying relevance and structure of papers between journals (Yang et al., 2019). The more frequently two journals are co-cited, the stronger is their linkage (Wang et al., 2020a). According to VOSviewer, AutCon publications have 65920 different references from 29781 journals. The journal co-citation network of AutCon publications is shown in Figure 5.
In Figure 5, only the journals cited at least 20 times are displayed. The size of a node represents the cited frequency and the thickness of the line denotes the relationship strength between two journals. It is obvious that AutCon is the largest node in Figure 5. As stated in Section 2.2, it is logical that a journal cites itself. Expect for AutCon, Journal of Construction Engineering and Management, Journal of Computing in Civil Engineering, and Advanced Engineering Informatics are top journals that are cited by AutCon publications, with 2272, 2130, 1902, and 1291 times, respectively. Many other journals also played critical roles, such as Energy and Buildings, Building and Environment, Journal of Information Technology in Construction, and Computer-Aided Civil and Infrastructure Engineering. A majority of these top journals belong to "Engineering, Civil" and "Construction \& Building Technology" in the WoS category.

\subsection{The evolution of AutCon themes}

To discover the main topics and thematic areas of AutCon publications, in this section, we use the SciMAT software to carry out conceptual bibliometric analyses based on coword bibliographic networks (Laengle et al., 2020). The author keywords are used, which are the refinement of a theme and can represent authors' understanding of their studies (Tang et al., 2018, 2020). In a research field, frequently used author keywords are usually associated with an important research topic (Uddin \& Khan, 2016). Before analysis, a normalization process is given, in which singular and plural forms of keywords are joined. The keywords with different forms but with the same meaning are joined. To carry out the thematic evolution analysis of the journal, we divide the data into four consecutive sub-periods: 2000-2004, 2005-2009, 2010-2014, and 2015-2019.

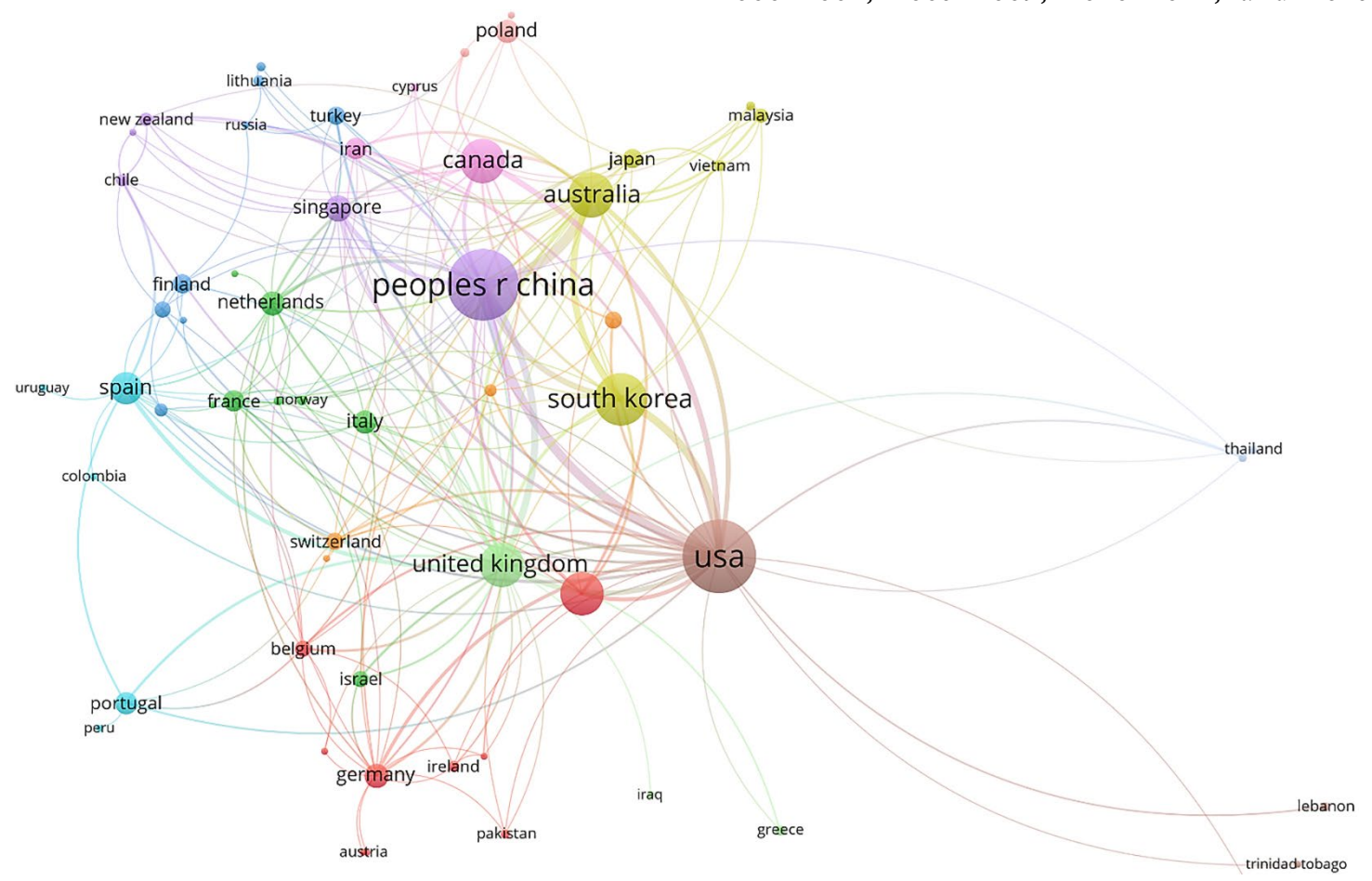

Figure 4. The country/region co-authorship network 


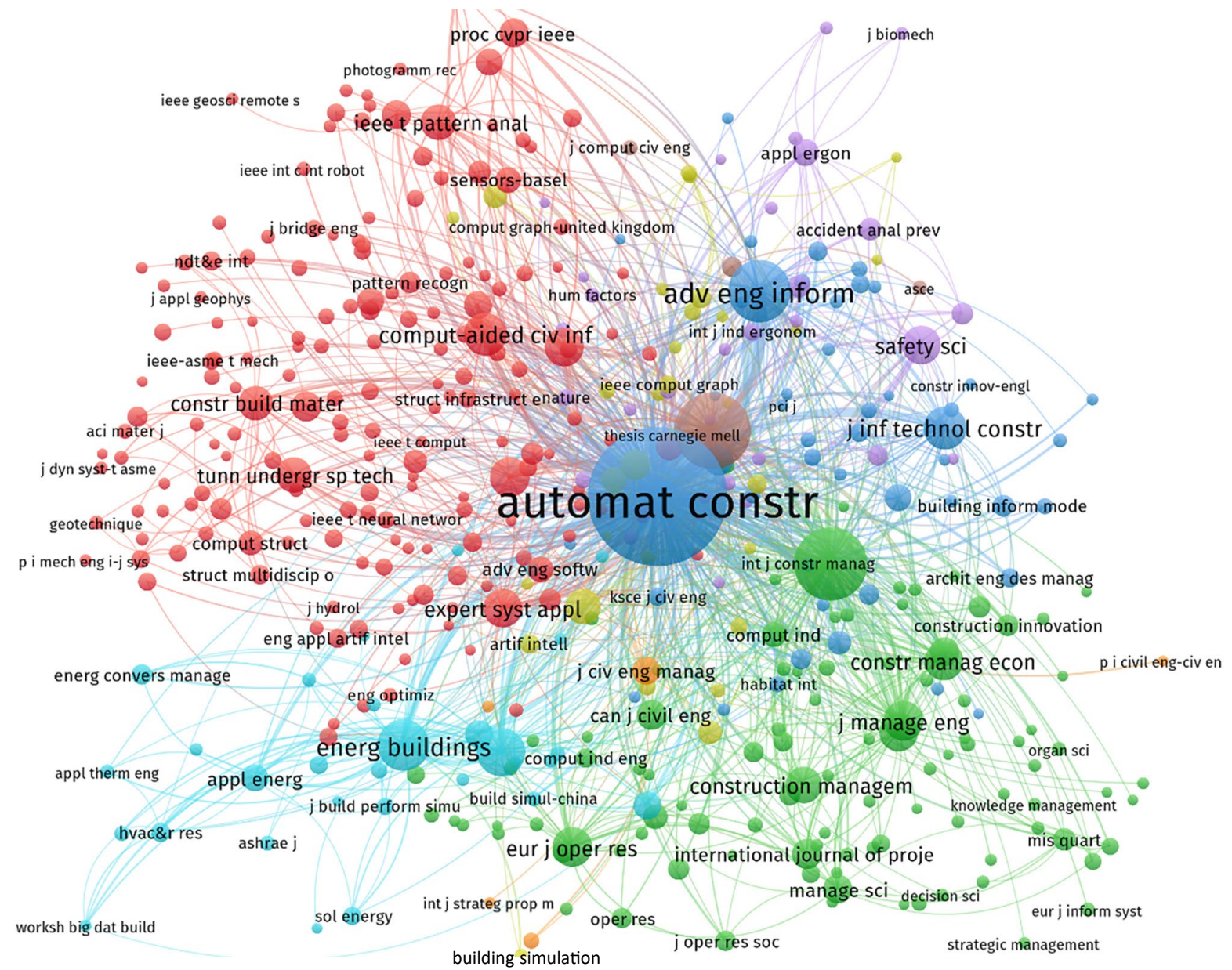

Figure 5. Journal co-citation network

To analyze the most watched and highlighted themes of AutCon publications, a strategic diagram is built based on the number of citations received for each theme. In the following, the strategic diagrams in each sub-period will be displayed and the performance measures for corresponding themes are provided.

The first sub-period (2000-2004). In this sub-period, a total of 267 documents of AutCon are considered. According to the strategic diagram plotted in Figure 6, AutCon focused on 14 themes, including 8 major themes (in the upper-right and lower-right quadrant). According to the performance measures (see Table 7), we can find that (1) two motor themes, Controller and Autonomous-landvehicle obtained a few citations and hence did not have much impact; (2) several basic and transversal themes, such as Buildings, Building Management Systems, and Accidents received many citations; (3) the isolated themes including Web services, Cost, and Earthwork, also had great influence. Note that, in this sub-period, only 83 documents $(31.09 \%)$ are related to some themes. Therefore, there is a low number of keywords detected to make the co-word analysis.

The second sub-period (2005-2009). In this sub-period, a total of 405 documents were published. AutCon pivoted on 29 themes with 15 major themes (Figure 7).
Table 7. Performance measures of themes in the sub-period 2000-2004 (Threshold: 2)

\begin{tabular}{|l|c|c|c|}
\hline \multicolumn{1}{|c|}{ Theme name } & $\begin{array}{c}\text { Number of } \\
\text { documents }\end{array}$ & $\begin{array}{c}\text { Number of } \\
\text { citations }\end{array}$ & $h$-index \\
\hline Buildings & 4 & 121 & 4 \\
\hline Earthwork & 3 & 45 & 3 \\
\hline $\begin{array}{l}\text { Management } \\
\text { information systems }\end{array}$ & 3 & 37 & 2 \\
\hline $\begin{array}{l}\text { Building management } \\
\text { systems }\end{array}$ & 3 & 92 & 3 \\
\hline Web services & 2 & 69 & 2 \\
\hline $\begin{array}{l}\text { Artificial neural } \\
\text { network }\end{array}$ & 2 & 41 & 2 \\
\hline
\end{tabular}

Similar to the former stage, several motor themes such as Life cycle cost, Construction material, Pavement, Evolutionary strategy, Layers, did not have many citations. The basic themes Simulation, Intelligent buildings (Zavadskas, 2010), and Genetic algorithms, received a high number of citations (see Table 8). Four specific themes, Laser scanner, Building information modeling, Excavator, and Cracks, also have high citation scores. Note that in this sub-period, 138 (34.07\%) documents were associated with some themes. Therefore, we can find more keywords. 


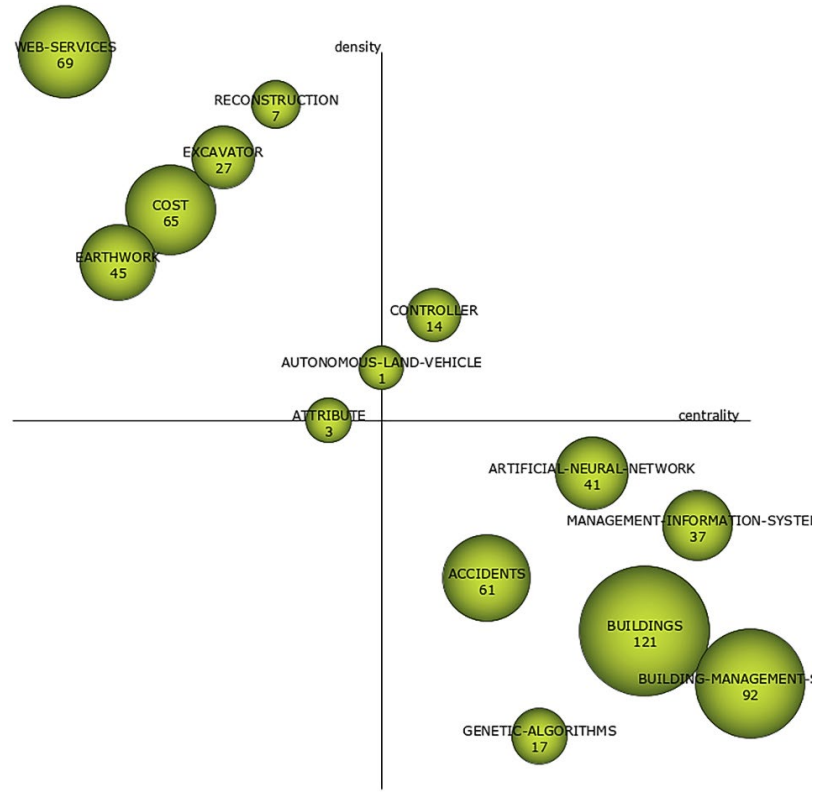

Figure 6. The strategic diagram of the sub-period 2000-2004

Table 8. Performance measures of themes in the sub-period 2005-2009 (Threshold: 2)

\begin{tabular}{|l|c|c|c|}
\hline \multicolumn{1}{|c|}{ Theme name } & $\begin{array}{c}\text { Number of } \\
\text { documents }\end{array}$ & $\begin{array}{c}\text { Number of } \\
\text { citations }\end{array}$ & $h$-index \\
\hline Genetic algorithms & 7 & 224 & 6 \\
\hline Simulation & 6 & 281 & 6 \\
\hline Intelligent building & 3 & 268 & 3 \\
\hline $\begin{array}{l}\text { Building } \\
\text { information } \\
\text { modeling }\end{array}$ & 3 & 191 & 3 \\
\hline Virtual world & 3 & 83 & 3 \\
\hline Laser scanner & 2 & 262 & 2 \\
\hline Case study & 2 & 104 & 2 \\
\hline Excavator & 2 & 111 & 2 \\
\hline Ontology & 2 & 56 & 2 \\
\hline $\begin{array}{l}\text { Artificial neural } \\
\text { network }\end{array}$ & 2 & 51 & 2 \\
\hline $\begin{array}{l}\text { Construction } \\
\text { material }\end{array}$ & 2 & 16 & 2 \\
\hline Life cycle cost & 2 & 37 & 2 \\
\hline Robot arm & 2 & 36 & 2 \\
\hline Projects & 2 & & 2 \\
\hline Operations & 2 & 15 & \\
\hline
\end{tabular}

The third sub-period (2010-2014). In this sub-period, we find more themes (37) than previous two subperiods based on a total of 739 documents. According to Figure 8 and Table 9, we can observe that Building information modeling has the best performance with more than 1000 citations. Some novel themes also have a good performance, such as Decision support systems, Measurement, and Safety risk.

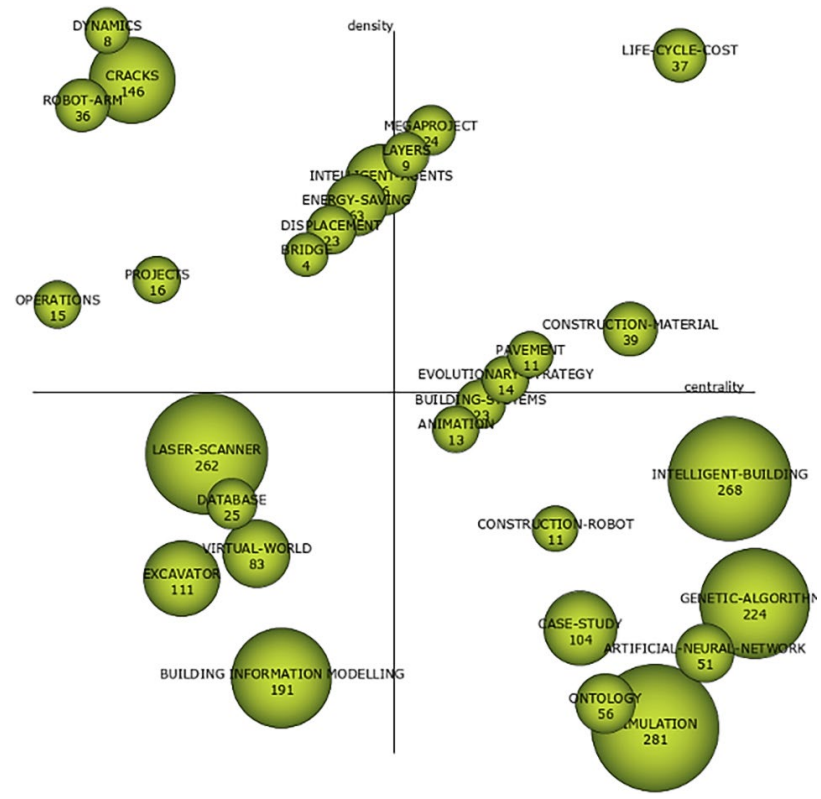

Figure 7. The strategic diagram of the sub-period 2005-2009

Table 9. Performance measures of themes in the sub-period 2010-2014 (Threshold: 2)

\begin{tabular}{|l|c|c|c|}
\hline \multicolumn{1}{|c|}{ Theme name } & $\begin{array}{c}\text { Number of } \\
\text { documents }\end{array}$ & $\begin{array}{c}\text { Number of } \\
\text { citations }\end{array}$ & $h$-index \\
\hline $\begin{array}{l}\text { Building information } \\
\text { modelling }\end{array}$ & 23 & 1082 & 17 \\
\hline Simulation & 15 & 364 & 9 \\
\hline $\begin{array}{l}\text { Decision support } \\
\text { systems }\end{array}$ & 5 & 105 & 5 \\
\hline Energy saving & 5 & 275 & 5 \\
\hline $\begin{array}{l}\text { Artificial neural } \\
\text { network }\end{array}$ & 4 & 87 & 4 \\
\hline Representation & 4 & 74 & 3 \\
\hline Uncertainty & 2 & 24 & 3 \\
\hline Dynamics & 2 & 39 & 2 \\
\hline Social network & 2 & 42 & 2 \\
\hline Life cycle cost & 2 & 349 & 2 \\
\hline Measurement & 2 & 133 & 2 \\
\hline Safety risk & 2 & 141 & 2 \\
\hline $\begin{array}{l}\text { Construction } \\
\text { professional }\end{array}$ & 2 & 39 & 2 \\
\hline HAVC system & 2 & 2 \\
\hline Database & 2 & & \\
\hline
\end{tabular}

The fourth sub-period (2015-2019). In the last subperiod (see Figure 9 and Table 10), the theme Building information modeling continued to maintain its dominant position. Although in this sub-period, only $20.57 \%$ (230) of documents were associated with somes Artificial neural network theme, there are a large number of themes because of the high number of documents. 


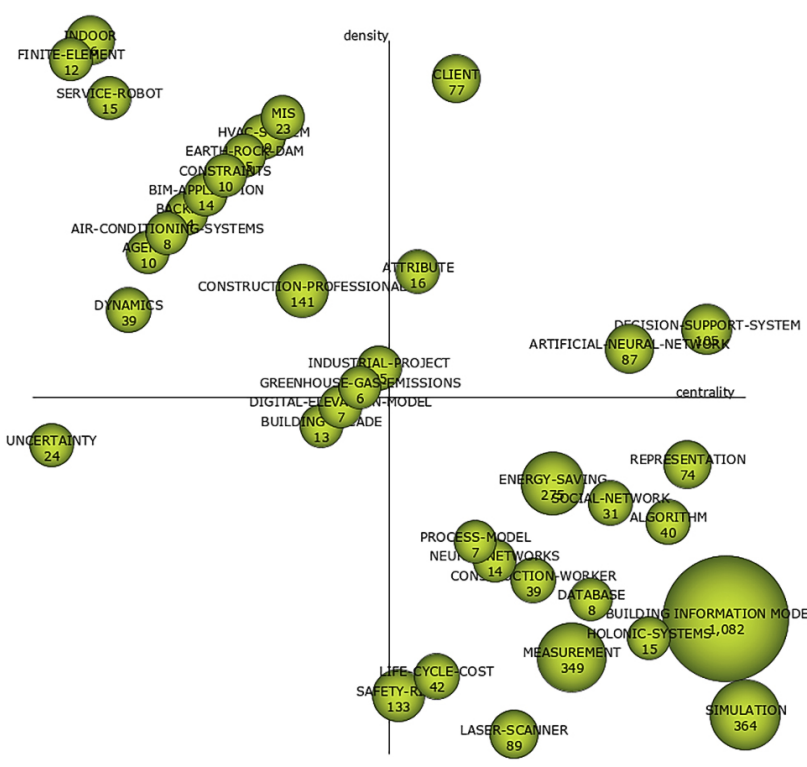

Figure 8. The strategic diagram of the sub-period 2010-2014

Table 10. Performance measures of themes in the sub-period 2015-2019 (Threshold: 3)

\begin{tabular}{|l|c|c|c|}
\hline \multicolumn{1}{|c|}{ Theme name } & $\begin{array}{c}\text { Number of } \\
\text { documents }\end{array}$ & $\begin{array}{c}\text { Number of } \\
\text { citations }\end{array}$ & $h$-index \\
\hline $\begin{array}{l}\text { Building information } \\
\text { modelling }\end{array}$ & 60 & 1553 & 21 \\
\hline Simulation & 14 & 127 & 7 \\
\hline $\begin{array}{l}\text { Convolutional neural } \\
\text { network }\end{array}$ & 5 & 59 & 4 \\
\hline $\begin{array}{l}\text { Artificial neural } \\
\text { network }\end{array}$ & 4 & 26 & 3 \\
\hline Buildings & 4 & 110 & 3 \\
\hline Construction projects & 3 & 50 & 3 \\
\hline $\begin{array}{l}\text { Building automation } \\
\text { system }\end{array}$ & 3 & 12 & 3 \\
\hline Smart building & 3 & 52 & 3 \\
\hline Uncertainty & 3 & 18 & 2 \\
\hline Energy saving & 3 & 57 & 3 \\
\hline Errors & 3 & 21 & 3 \\
\hline
\end{tabular}

Generally, we can find that in all four sub-periods, basic and transversal themes received more citations and impacts. It is reasonable that these themes are more likely to obtain citations and attention. This shows that the identification of these basic and transversal themes is consistent (Cobo et al., 2011a).

We have analyzed the themes in each sub-period, next, we further discuss the thematic evolution of AutCon.

In each sub-period, the keywords are different in terms of lexicography or quantity. That is, the journal terminology evolves through the period using various keywords to describe the content of it. Therefore, through the pe-

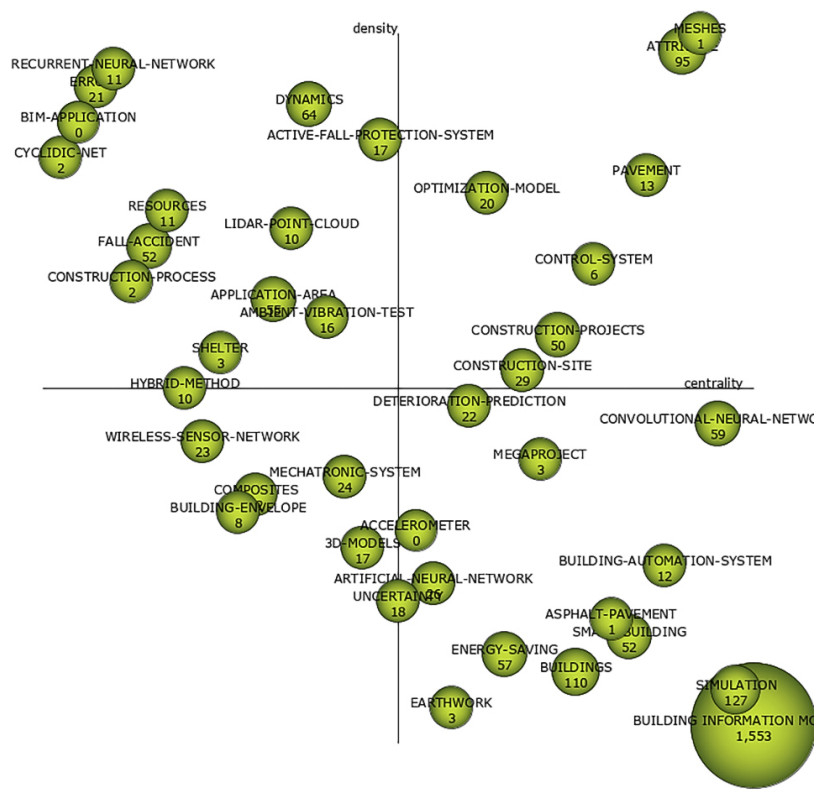

Figure 9. The strategic diagram of the sub-period 2015-2019

riod, some themes disappeared and some new themes appeared. On another note, some keywords appeared during several consecutive or all sub-periods and some keywords only appeared in some sub-periods. Figure 10 presents the evolution status of keywords in AutCon publications. A circle represents a sub-period and the number in it denotes the number of keywords. The arrow between two circles represents the number of shared keywords and the inclusion index (Cobo et al., 2011a) (in parentheses). The inclusion index is calculated according to:

$$
\text { Inclusion index }=\frac{\#(U \cap V)}{\min (\# U, \# V)},
$$

where $U$ represents each detected theme in a sub-period and $V$ represents each detected theme in the next subperiod. "\#" denotes the number of themes.

The arrow pointing upward denotes the keywords did not appear in the next sub-period and the arrow pointing downward indicates the new keywords in the sub-period (Cobo et al., 2011a). For instance, the second sub-period has 138 keywords, in which 86 keywords remain in the third sub-period and 52 keywords are not kept in the third sub-period. From Figure 10, we can find that the number of keywords in each sub-period and the number of shared keywords between consecutive sub-periods increase dramatically.

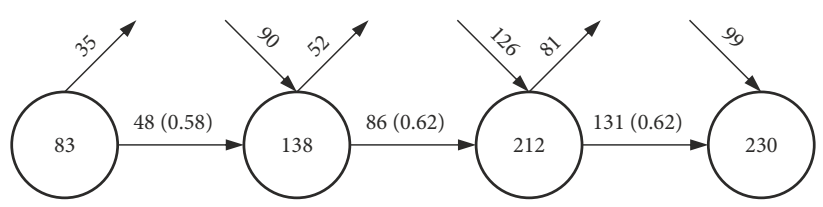

Figure 10. The overlapping map of four sub-periods 


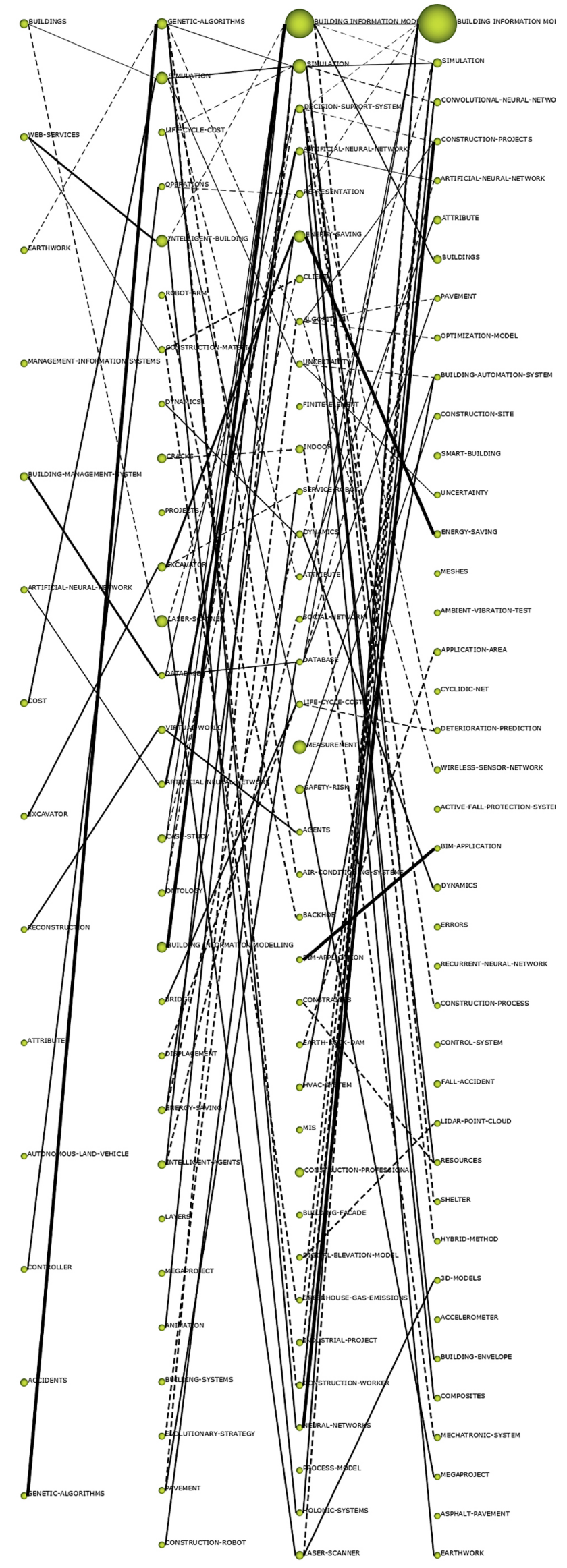

Figure 11. The thematic evolution of AutCon publications

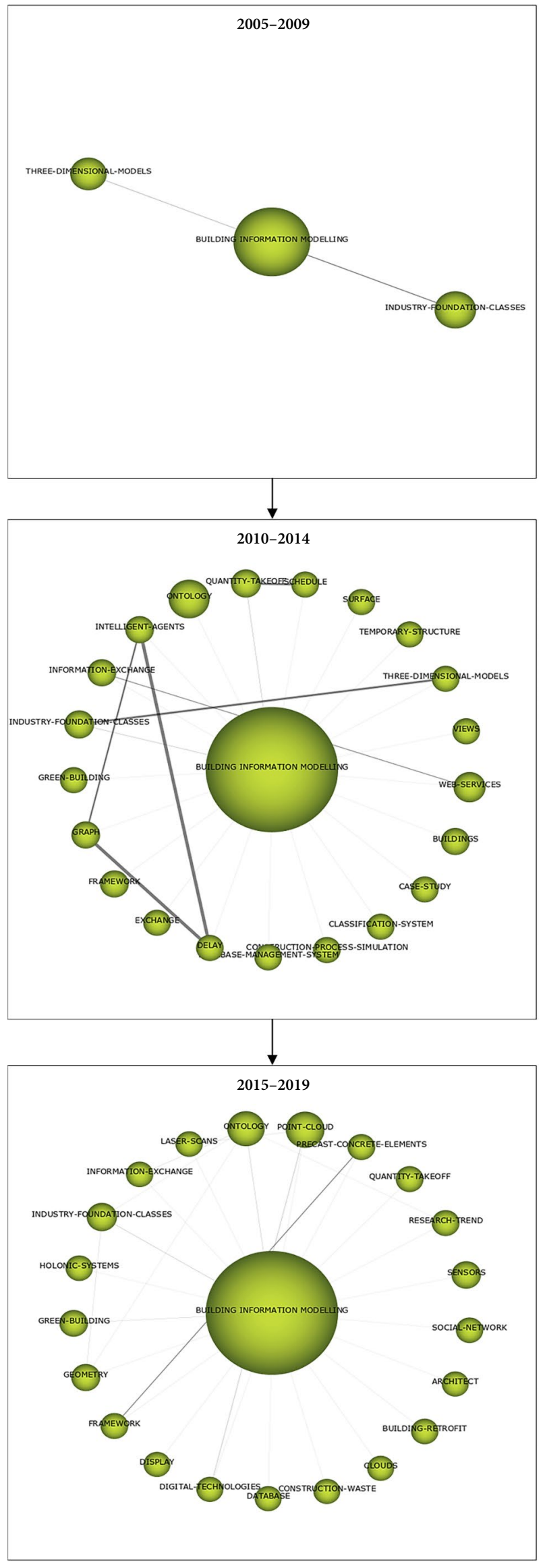

Figure 12. The Building information modeling area 
Table 11. Performance measures of detected thematic areas

\begin{tabular}{|l|c|c|c|}
\hline \multicolumn{1}{|c|}{ Theme name } & $\begin{array}{c}\text { Number } \\
\text { of documents }\end{array}$ & $\begin{array}{c}\text { Number } \\
\text { of citations }\end{array}$ & $\begin{array}{c}\text { Number } \\
\text { of periods }\end{array}$ \\
\hline $\begin{array}{l}\text { Building information } \\
\text { modelling }\end{array}$ & 86 & 2826 & 3 \\
\hline Simulation & 35 & 772 & 3 \\
\hline Energy saving & 9 & 395 & 3 \\
\hline Genetic algorithms & 8 & 241 & 2 \\
\hline Buildings & 8 & 231 & 2 \\
\hline
\end{tabular}

The thematic evolution of AutCon publications is displayed in Figure 11. A solid line indicates that the connected themes share the same name and a dotted line denotes that the linked themes have keywords different from the name of the themes. The size of the sphere reflects the number of documents of each theme, and the thickness of the line is proportional to the inclusion index. As we can see from Figure 11, the themes are of high degree of interconnection. Several main thematic areas and their corresponding performance measures are provided in Table 11. Analyzing Figure 11 and Table 11, we can find that the AutCon themes presents great dispersion, given that many identified themes are isolated. As we can see, Building information modeling is the most talked about topic in AutCon publications. Furthermore, this area evolves in an increasing way (see Figure 12). Half of the top 30 most cited papers focused on this topic (see Table 6). It is expected that the journal would continue to focus on this area. Other focused topics include simulation, energy saving and genetic algorithms (Ponz-Tienda et al., 2013).

\section{Conclusions}

The objective of this paper was to trace the evolution status of the journal "Automation in Construction". This study provided a bibliometric overview for AutCon publications between 1992 and 2019. Our work was mainly based on two parts: 1) publication and citation statistics and 2) network and science mapping analyses. The main findings of this study can be summarized as follows:

1. AutCon is one of the most influential journals in the field of building, construction and civil. The result showed that AutCon has a significant increase regarding publications and citations in the last decade. This suggested that AutCon received increasingly wide attention and reputation from scientific community.

2. The USA was the most prolific country with the highest number of publications, citations and hindex, followed by China and the UK. Some developing countries/regions also appeared in the top 30 list. It is expected that other developing countries/ regions will increase their influence in AutCon. The top institutes contributing to the journal were the Hong Kong Polytechnic University and Georgia University of Technology. AutCon has a diverse distribution regarding countries/regions and institutes.
3. Inter-institutional and inter-country/region collaboration were popular in this journal. Furthermore, AutCon also had strong connections with the journals in engineering, construction and building. AutCon publications mainly cited publications from Journal of Construction Engineering and Management, Journal of Computing in Civil Engineering, and Advanced Engineering Informatics. Journal of Construction Engineering and Management, Energy and Buildings, and Journal of Computing in Civil Engineering cited AutCon publications more frequently.

4. A majority of highly cited papers focused on building information modeling. It is expected that this topic will still maintain its heat in the future. Expect for building information modeling, we observed that AutCon publications presented low cohesion. This reflects that the journal published refereed material on all aspects and the scope of AutCon is broad including the use of information technologies in design, engineering, construction technologies, and management of constructed facilities (Boscardin et al., 2019; Yepes et al., 2015).

5. Based on the thematic evolution analysis, we found that the building information modeling run through the development of the journal. We also identified several emergent themes that attracted the interest of the community such as the use of convolutional neural network and artificial neural network in civil engineering field.

Future research directions of AutCon could focus on energy saving materials and smart buildings. Traditional construction mode consumes a lot of energy and pollutes the environment seriously, and the accumulated contradictions and problems are becoming increasingly prominent. It is a general trend to vigorously promote green building materials, reduce building consumption and environmental pollution. Furthermore, emerging deep learning and neural network methods are worthy to be investigated in construction automation such as predicting or assessing problems.

This study also has limitations. A bibliometric study provides an overview regarding a specific time period. The data are dynamic and the results may change over time. It is hoped that our study will help editors and readers of this journal. In the future, it is important to continue to attract high level work to publish in this journal. The journal can invite experts in the fields that are consistent with the topic of AutCon to contribute submissions. Simultaneously, it is suggested that editors pay attention to the academic research trends of related subjects and organize the research results published in time. Through our study, readers can also know topics that have potential to publish in this journal.

\section{Acknowledgments}

The work was supported by the National Natural Science Foundation of China (71771156, 71971145). 


\section{Disclosure statement}

Authors do not have any competing financial, professional, or personal interests from other parties.

\section{References}

Boscardin, J. T., Yepes, V., \& Kripka, M. (2019). Optimization of reinforced concrete building frames with automated grouping of columns. Automation in Construction, 104, 331-340. https://doi.org/10.1016/j.autcon.2019.04.024

Bornmann, L., \& Haunschild, R. (2016). Overlay maps based on Mendeley data: The use of altmetrics for readership networks. Journal of the Association for Information Science and Technology, 67(12), 3064-3072. https://doi.org/10.1002/asi.23569

Canas-Guerrero, I., Mazarron, F. R., Calleja-Perucho, C., PouMerina, A., Calleja-Perucho, C., \& Suarez-Tejero, M. F. (2013). Analysis of research activity in the field "Engineering, Civil" through bibliometric methods. Engineering Structures, 56, 2273-2286. https://doi.org/10.1016/j.engstruct.2013.08.038

Canas-Guerrero, I., Mazarron, F. R., Calleja-Perucho, C., \& PouMerina, A. (2014). Bibliometric analysis in the international context of the "Construction \& Building Technology" category from the Web of Science database. Construction and Building Materials, 53, 13-25.

https://doi.org/10.1016/j.conbuildmat.2013.10.098

Cobo, M. J., López-Herrera, A. G., Herrera-Viedma, E., \& Herrera, F. (2011a). An approach for detecting, quantifying, and visualizing the evolution of a research field: A practical application to the Fuzzy Sets Theory field. Journal of Informetrics, 5(1), 146-166. https://doi.org/10.1016/j.joi.2010.10.002

Cobo, M. J., López-Herrera, A. G., Herrera-Viedma, E., \& Herrera, F. (2011b). Science mapping software tools: Review, analysis, and cooperative study among tools. Journal of the American Society for Information Science and Technology, 62(7), 1382-1402. https://doi.org/10.1002/asi.21525

Cobo, M. J., López-Herrera, A. G., Herrera-Viedma, E., \& Herrera, F. (2012). SciMAT: A new science mapping analysis software tool. Journal of the American Society for Information Science and Technology, 63(8), 1609-1630. https://doi.org/10.1002/asi.22688

Cobo, M. J., Chiclana, F., Collop, A., de Ona, J., \& HerreraViedma, E. (2014). A bibliometric analysis of the intelligent transportation systems research based on science mapping. IEEE Transactions on Intelligent Transportation Systems, 15(2), 901-908. https://doi.org/10.1109/TITS.2013.2284756

Dees, A. S. (2015). A bibliometric analysis of the scholarly publications of librarians at the University of Mississippi, 20082013. Journal of Academic Librarianship, 41(3), 241-245. https://doi.org/10.1016/j.acalib.2015.03.019

Derbe, G., Li, Y., Wu, D., \& Zhao, Q. (2020). Scientometric review of construction project schedule studies: trends, gaps and potential research areas. Journal of Civil Engineering and Management, 26(4), 343-363.

https://doi.org/10.3846/jcem.2020.12317

de Wilde, P. (2014). The gap between predicted and measured energy performance of buildings: A framework for investigation. Automation in Construction, 41, 40-49. https://doi.org/10.1016/j.autcon.2014.02.009

Gu, N., \& London, K. (2010). Understanding and facilitating BIM adoption in the AEC industry. Automation in Construction, 19(8), 988-999. https://doi.org/10.1016/j.autcon.2010.09.002
Hartley, J. (2019). Some reflections on being cited 10,000 times. Scientometrics, 118(1), 375-381.

https://doi.org/10.1007/s11192-018-2966-5

Hirsch, J. E. (2005). An index to quantify an individual's scientific research output. Proceedings of the National Academy of Sciences of the United States of America, 102(46), 16569-16572. https://doi.org/10.1073/pnas.0507655102

Hosseini, M. R., Martek, I., Zavadskas, E. K., Aibinu, A. A., Arashpour, M., \& Chileshe, N. (2018). Critical evaluation of offsite construction research: A Scientometric analysis. Automation in Construction, 87, 235-247.

https://doi.org/10.1016/j.autcon.2017.12.002

International Organization for Standardization. (2010). Building information modeling - Information delivery manual - Part 1: Methodology and format (ISO 29481-1:2010(E)). Geneva, Switzerland.

Kong, X. J., Shi, Y. J., Yu, S., Liu, J. Y., \& Xia, F. (2019). Academic social networks: Modeling, analysis, mining and applications. Journal of Network and Computer Applications, 132, 86-103. https://doi.org/10.1016/j.jnca.2019.01.029

Laengle, S., Lobos, V., Merigó, J. M., Herrera-Viedma, E., Cobo, M. J., \& De Baets, B. (2020). Forty years of fuzzy sets and systems: A bibliometric analysis. Fuzzy Sets and Systems, 402, 155-183. https://doi.org/10.1016/j.fss.2020.03.012

Liao, H. C., Tang, M., Li, Z. M., \& Lev, B. (2019). Bibliometric analysis for highly cited papers in operations research and management science from 2008 to 2017 based on Essential Science Indicators. Omega, 88, 223-236. https://doi.org/10.1016/j.omega.2018.11.005

Lim, S., Buswell, R. A., Le, T. T., Austin, S. A., Gibb, A. G. F., \& Thorpe, T. (2012). Developments in construction-scale additive manufacturing processes. Automation in Construction, 21, 262-268. https://doi.org/10.1016/j.autcon.2011.06.010

Meho, L. I., \& Yang, K. (2007). Impact of data sources on citation counts and rankings of LIS faculty: Web of science versus scopus and google scholar. Journal of the American Society for Information Science and Technology, 58(13), 2105-2125. https://doi.org/10.1002/asi.20677

Miranda, R., \& Garcia-Carpintero, E. (2018). Overcitation and overrepresentation of review papers in the most cited papers. Journal of Informetrics, 12(4), 1015-1030. https://doi.org/10.1016/j.joi.2018.08.006

Modak, N. M., Merigo, J. M., Weber, R., Manzor, F., \& Ortuzar, J. D. (2019). Fifty years of Transportation Research journals: A bibliometric overview. Transportation Research Part A: Policy and Practice, 120, 188-223.

https://doi.org/10.1016/j.tra.2018.11.015

Morkūnaite, Ž., Kalibatas, D., \& Kalibatienė, D. (2019). A bibliometric data analysis of multi-criteria decision making methods in heritage buildings. Journal of Civil Engineering and Management, 25(2), 76-99.

https://doi.org/10.3846/jcem.2019.8315

Navarro, I. J., Penades-Pla, V., Martinez-Munoz, D., Rempling, R., \& Yepes, V. (2020). Life cycle sustainability assessment for multi-critieria decision making in bridge design: A review. Journal of Civil Engineering and Management, 26(7), 690-704. https://doi.org/10.3846/jcem.2020.13599

Ponz-Tienda, J. L., Yepes, V., Pellicer, E., \& Moreno-Flores, J. (2013). The Resource Leveling Problem with multiple resources using an adaptive genetic algorithm. Automation in Construction, 29, 161-172.

https://doi.org/10.1016/j.autcon.2012.10.003 
Rossetto, D. E., Bernardes, R. C., Borini, F. M., \& Gattaz, C. C. (2018). Structure and evolution of innovation research in the last 60 years: review and future trends in the field of business through the citations and co-citations analysis. Scientometrics, 115(3), 1329-1363. https://doi.org/10.1007/s11192-018-2709-7

Schlueter, A., \& Thesseling, F. (2009). Building information model based energy/exergy performance assessment in early design stages. Automation in Construction, 18(2), 153-163. https://doi.org/10.1016/j.autcon.2008.07.003

Siebert, S., \& Teizer, J. (2014). Mobile 3D mapping for surveying earthwork projects using an Unmanned Aerial Vehicle (UAV) system. Automation in Construction, 41, 1-14.

https://doi.org/10.1016/j.autcon.2014.01.004

Singh, S., Dhir, S., Das, V. M., \& Sharma, A. (2020a). Bibliometric overview of the Technological Forecasting and Social Change journal: Analysis from 1970 to 2018. Technological Forecasting and Social Change, 154, 119963.

https://doi.org/10.1016/j.techfore.2020.119963

Singh, V., Verma, S., \& Chaurasia, S. S. (2020b). Mapping the themes and intellectual structure of corporate university: cocitation and cluster analyses. Scientometrics, 122(3), 12751302. https://doi.org/10.1007/s11192-019-03328-0

Succar, B. (2009). Building information modelling framework: A research and delivery foundation for industry stakeholders. Automation in Construction, 18(3), 357-375. https://doi.org/10.1016/j.autcon.2008.10.003

Tang, P. B., Huber, D., Akinci, B., Lipman, R., \& Lytle, A. (2010). Automatic reconstruction of as-built building information models from laser-scanned point clouds: A review of related techniques. Automation in Construction, 19(7), 829-843. https://doi.org/10.1016/j.autcon.2010.06.007

Tang, M., Liao, H. C., \& Su, S. F. (2018). A bibliometric overview and visualization of the International Journal of Fuzzy Systems between 2007 and 2017. International Journal of Fuzzy Systems, 20(5), 1403-1422.

https://doi.org/10.1007/s40815-018-0484-5

Tang, M., Liao, H. C., \& Tamasevicius, V. (2020). 15 years in Web of Science of the Transformations in Business and Economics: bibliometric and visual analyses. Transformations in Business and Economics, 19(1), 21-42.

Uddin, S., \& Khan, A. (2016). The impact of author-selected keywords on citation counts. Journal of Informetrics, 10, 11661177. https://doi.org/10.1016/j.joi.2016.10.004

Upham, S. P., \& Small, H. (2010). Emerging research fronts in science and technology: patterns of new knowledge development. Scientometrics, 83, 15-38.

https://doi.org/10.1007/s11192-009-0051-9

van Eck, N., \& Waltman, L. (2010). Software survey: VOSviewer, a computer program for bibliometric mapping. Scientometrics, 84, 523-538. https://doi.org/10.1007/s11192-009-0146-3

Vilutiene, T., Hosseini, M. R., Pellicer, E., \& Zavadskas, E. K. (2019a). Advanced BIM applications in the construction industry. Advances in Civil Engineering, 2019, 6356107. https://doi.org/10.1155/2019/6356107

Vilutiene, T., Kalibatiene, D., Hosseini, M. R., Pellicer, E., \& Zavadskas, E. K. (2019b). Building information modeling (BIM) for structural engineering: A bibliometric analysis of the literature. Advances in Civil Engineering, 2019, 5290690. https://doi.org/10.1155/2019/5290690

Volk, R., Stengel, J., \& Schultmann, F. (2014). Building Information Modeling (BIM) for existing buildings - literature review and future needs. Automation in Construction, 38, 109-127. https://doi.org/10.1016/j.autcon.2013.10.023
VOSviewer. (n.d.). https://www.vosviewer.com/

Wang, J. (2013). Citation time window choice for research impact evaluation. Scientometrics, 94, 851-872. https://doi.org/10.1007/s11192-012-0775-9

Wang, C., Lim, M. K., Zhao, L. F., Tseng, M. L., Chien, C. F., \& Lev, B. (2020a). The evolution of Omega-The International Journal of Management Science over the past 40 years: A bibliometric overview. Omega, 93, 102098. https://doi.org/10.1016/j.omega.2019.08.005

Wang, X. X., Xu, Z. S., Ge, Z. J., Zavadskas, E. K., \& Skačkauskas, P. (2020b). An overview of a leader journal in the field of transport: A bibliometric analysis of "Computer-Aided Civil and Infrastructure Engineering” from 2000 to 2019. Transport, 35(6), 557-575. https://doi.org/10.3846/transport.2020.14140

Xiong, X. H., Adan, A., Akinci, B., \& Huber, D. (2013). Automatic creation of semantically rich $3 \mathrm{D}$ building models from laser scanner data. Automation in Construction, 31, 325-337. https://doi.org/10.1016/j.autcon.2012.10.006

Yang, L. J., Han, L. X., \& Liu, N. X. (2019). A new approach to journal co-citation matrix construction based on the number of co-cited articles in journals. Scientometrics, 120, 507-517. https://doi.org/10.1007/s11192-019-03141-9

Yepes, V., Martí, J. V., \& García-Segura, T. (2015). Cost and $\mathrm{CO}_{2}$ emission optimization of precast-prestressed concrete $\mathrm{U}$ beam road bridges by a hybrid glowworm swarm algorithm. Automation in Construction, 49, 123-134.

https://doi.org/10.1016/j.autcon.2014.10.013

Yu, D. J., \& Pan, T. X. (2021). Tracing knowledge diffusion of TOPSIS: A historical perspective from citation network. Expert Systems with Applications, 168, 114238. https://doi.org/10.1016/j.eswa.2020.114238

Yu, D. J., \& Sheng, L. B. (2020). Knowledge difusion paths of blockchain domain: the main path analysis. Scientometrics, 125, 471-497. https://doi.org/10.1007/s11192-020-03650-y

Yu, D. J., Xu, Z. S., \& Antuchevičienè, J. (2019). Bibliometric analysis of the Journal of Civil Engineering and Management between 2008 and 2018. Journal of Civil Engineering and Management, 25(5), 402-410. https://doi.org/10.3846/jcem.2019.9925

Zahedi, Z., \& Haustein, S. (2018). On the relationships between bibliographic characteristics of scientific documents and citation and Mendeley readership counts: A large-scale analysis of Web of Science publications. Journal of Informetrics, 12(1), 191-202. https://doi.org/10.1016/j.joi.2017.12.005

Zavadskas, E. K. (2010). Automation and robotics in construction: International research and achievements. Automation in Construction, 19(3), 286-290.

https://doi.org/10.1016/j.autcon.2009.12.011

Zhang, S. J., Teizer, J., Lee, J. K., Eastman, C. M., \& Venugopal, M. (2013). Building information modeling (BIM) and safety: Automatic safety checking of construction models and schedules. Automation in Construction, 29, 183-195. https://doi.org/10.1016/j.autcon.2012.05.006

Zhou, W., Xu, Z. S., \& Zavadskas, E. K. (2019). A bibliometric overview of the International Journal of Strategic Property Management between 2008 and 2019. International Journal of Strategic Property Management, 23(6), 366-377. https://doi.org/10.3846/ijspm.2019.10535

Zhou, W., Xu, Z. S., Zavadskas, E. K., \& Laurinavičius, A. (2020). The knowledge domain of the Baltic Journal of Road and Bridge Engineering between 2006 and 2019. The Baltic Journal of Road and Bridge Engineering, 15(2), 1-30. https://doi.org/10.7250/bjrbe.2020-15.470 